\title{
PT・OT・アスリートのためのプログラミングとマイコン電子エ作入門（1） プログラミングとマイコンを用いた電子エ作
}

\author{
増田 正 $^{1}$, 大路駿 ${ }^{2 \dagger}$ \\ 1 福島大学共生システム理工学類, ${ }^{2}$ 東京医科歯科大学医学部附属病院
}

要旨：近年, 安価で使い勝手の良いマイクロコンピュータ（マイコン）や新たなプログラミング言語, プログラム開発支援ソ フトウェアが開発されてきている，理学療法や作業療法，スポーツ科学などの分野でも，これらを活用することにより，新た な研究の展開や臨床現場での効率的なデー夕収集などが実現できるものと期待される. 工学系の分野では多くの方がこれらに 関する知識や経験を有していると考えられるが, 医療やスポーツ科学が専門の方にとっては, どのような技術が存在して，何 が可能なのかを知る機会は多くないものと推察される.そこで, マイコンを活用した計測装置の開発およびパソコンやタブレッ ト端末でのプログラミングについて解説した。 また，マイコンとパソコン，タブレットを連動させた計測システムの製作方法 についても取り上げた。本稿では 4 回を予定している解説記事の第 1 回目として, 全体像が掴めるように概略を述べた.

キーワード：マイコン, プログラミング, タブレット, 計測, 解析

\section{1. プログラミングの必要性}

理学療法や作業療法, スポーツ科学の分野においても, コンピュータの利用は不可欠となってきている. 研究目的 や臨床現場での利用において, 市販されている計測装置や 解析ソフトウェアなどの既存製品で目的を達成することが 可能であれば, 自分自身で計測装置やプログラムを作成す る必要はないであろう.

しかしながら, 既存の計測装置では目的を達成すること ができない場合や，オリジナルな研究を実施したいとき， あるいは日常の臨床現場での測定を自動化したいときなど には, 自ら計測装置を製作したり, 独自の解析処理プログ ラムを作成する必要が生じる。また, 計測装置の製作やプ ログラミングを自ら行わない場合でも，基本的な知識を身 に付けておけば，これらの開発を企業に依頼する際に現実 的に実現可能な仕様を呈示することができるようになるで あろう。

一方で, 理学療法や作業療法, スポーツ科学の教育課程 においては，プログラミングや電子回路に関する教育はほ とんど実施されていないのが現状である。 そのため, これ らのことを勉強するためには, 大学の研究室で講習を受け たり，あるいは自ら情報を収集する必要がある。

2019 年 9 月 30 日受付

† ₹ 113-8519 東京都文京区湯島 1-5-45

東京医科歯科大学医学部附属病院スポーツ医学診療センター・アス レティックリハビリテーション部門

大路駿介

Tel\&Fax: 03-5803-4721

E-mail: ohji.spt@tmd.ac.jp
幸いなことに，近年，安価で使い勝手の良いマイクロコ ンピュータ（マイコン）や，新たなプログラミング言語, プログラム開発支援ソフトウェアが開発され，これらの使 い方を独学で習得することも容易になってきている.さら に，プログラムを作成する際に利用するソフトウェアの多 くは無料で入手でき, 使い方に関する解説記事もインター ネット上に多数公開されている. ところが, これらの情報 の存在に気がつかず，あるいは気がついていても，まず第 一歩として何を行えば良いのかが分からないと, 大量の有 用な情報に辿り着くことができない.

近年, バイオメカニズム学会においては, 理学療法や作 業療法を専門分野とする会員が増加してきた. また, 従来 より, スポーツ科学を専門とする会員も多数存在する. そ こで, 理工学系の会員にとっては極めて初歩的な内容では あるが, 理学療法や作業療法, スポーツ科学を専門とする 会員や学会誌の読者に役に立てて頂けることを目指して本 連載を企画した。作成する装置やプログラムとして，PT, OT, スポーツ分野の方の興味を引くような題材を取り上げ たが, これらの分野以外にも, 看護や心理など, 理工学を 専門としていない幅広い読者の方々にも参考にして頂ける ものと思う。

\section{2. マイコンの種類と使用例}

マイコンとは半導体部品としての CPU 集積回路 (チップ) の意味もあるが, ここでは CPU と周辺回路をプリント基板 に搭載したものを指している．様々な種類のマイコンが販 売されているが, 近年特に注目を集めているのが Arduino(ア ルデュイーノ）と Raspberry Pi（ラズベリー・パイ）である. 
これらに関しては, 書籍も多数出版されており ${ }^{1-3)}$, ネット 上にも豊富な情報がある。

\section{1 Arduino}

Arduino は本解説で取り上げるマイコンで, 名刺よりも小 さいサイズの基板に CPU と周辺回路, 外部接続用の端子が 搭載されている (図 1) ${ }^{1,2)}$.プログラムの作成はパソコン で行い,これをUSB ケーブルで接続した Arduinoに転送し て実行する. 電源はUSB 経由でパソコンから供給されるが, 大電流が必要な場合や, Arduinoを単独で動作させる場合に は, ACアダプタや電池などの電源を接続する. 一旦プログ ラムを転送すると, パソコンから切り離しても, 外部電源 が接続されていれば単独で動作させることができる.

Arduino には Windows や MacOS のようなオペレーティ ングシステム（OS）は搭載されておらず, 実行形式のプロ グラムだけがメモリに格納される. 電源の投入時や基板上 のリセットスイッチを押したとき, あるいはパソコンから のリセット信号を受信したときに初期状態に戻る. 初期化 されると, プログラムの初期化部分が 1 回実行された後, 繰り返し部分が無限に繰り返して実行される.

デジタルとアナログの入出力端子があり, これらにスイ ッチやセンサなどの入力装置や, 発光ダイオード (LED), モータ, 液晶表示などの出力装置を接続する. パソコンゃ タブレットとはUSB ケーブルや Bluetooth 無線を使って情 報交換をすることができる.

Arduino には多数のバージョンがある. 図 1 に示した Arduino UNO が代表的であるが, その他にも端子の数を 増やした Arduino MEGA や, より高速な CPUを搭載した Arduino Due どがある. Arduino UNO の場合には, プロ グラムを格納するフラッシュメモリは $32 \mathrm{~KB}$ (キロバイト) の容量しか無く, またデー夕を保存できるメモリも $2 \mathrm{~KB}$ と 少ないので, 複雑なプログラムを実行したり, 大量のデー 夕を保存したりすることはできない.

Arduino のプログラムを作るためには, 専用の無償ソフ トウェア Arduino IDE をパソコンにインストールして実行 する.ソフトウェアを起動すると, 図 2 のような画面が表

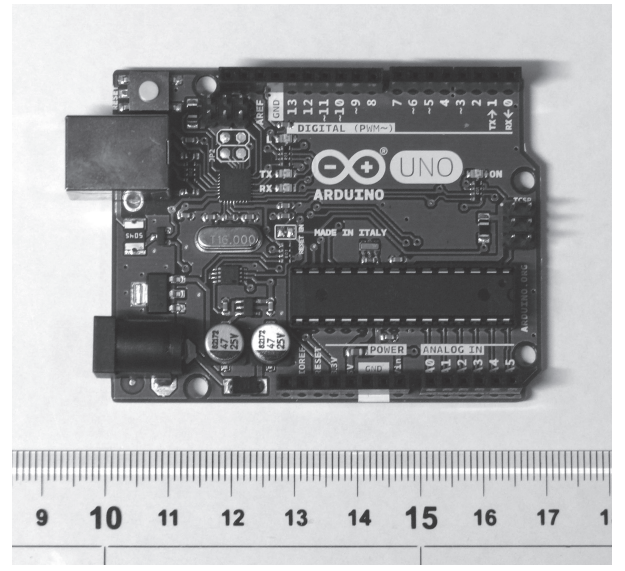

図 1 Arduino UNO の外観
示されるので, この中に英数字と記号をプログラミング言 語の規則に従って並べたコードを記入する．記入が完了し た後, 右向き矢印アイコンの実行ボタンをクリックすると, プログラムが実行形式に変換されて USB ケーブルで接続さ れた Arduinoに転送され, Arduino 上で実行される。

\section{2 Raspberry $\mathrm{Pi}$}

Raspberry Pi は, 見かけはArduinoと似ているが, Raspbian という Linux 系 OS を搭載したパソコンに近いシ ステムである（図 3).

OS アプログラムはマイクロ SDカードに保存する. HDMI ビデオ端子と USB 端子を有しているので, ディスプ レイとキーボード, マウス, ACアダプタを接続すると, パ ソコンと同じように扱うことができる（図 4).

また, LAN (イーサネット) 端子を持っているので, こ れを使ってネットワークに接続すると他のコンピュータと のファイル交換や, 別のパソコンからのログインなどを行 うことができる。

Raspberry Pi 単独でプログラムを作成して実行すること も可能であるが, パソコンで開発して実行した方が効率が 良い. パソコンから, Raspberry Pi を制御する方法として

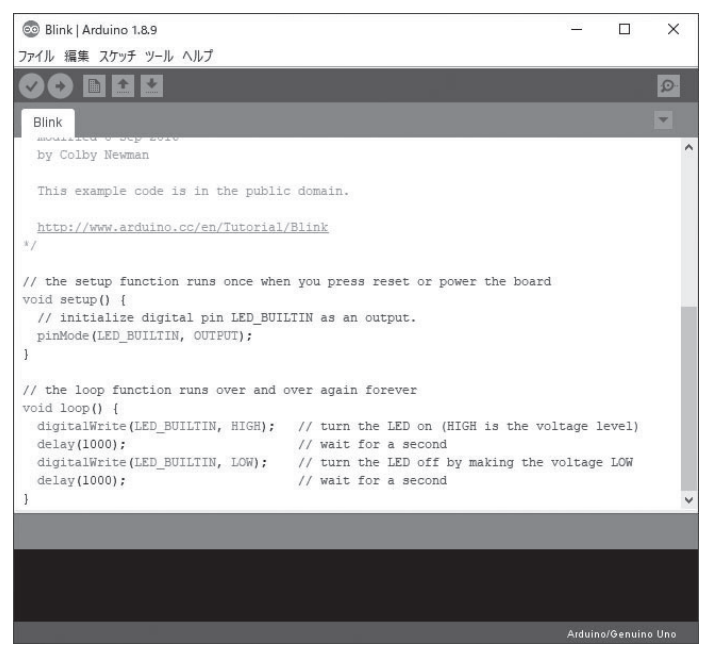

図 2 Arduino IDE の画面

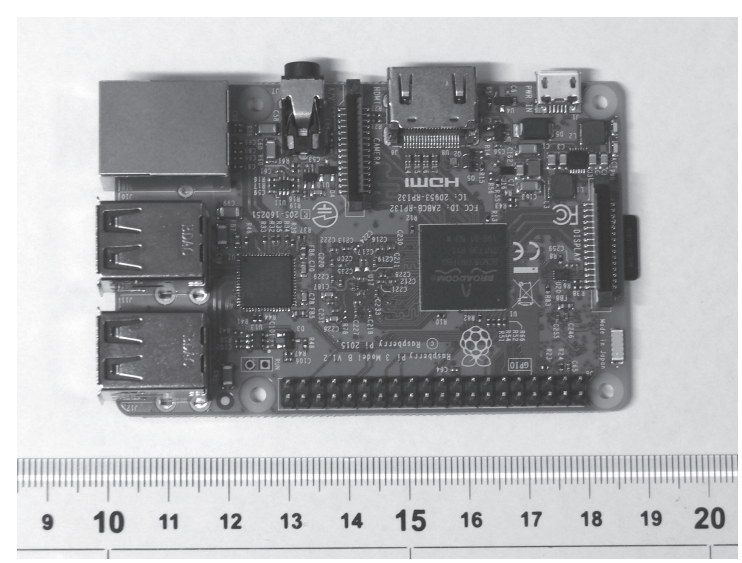

図 3 Raspberry Pi の外観 


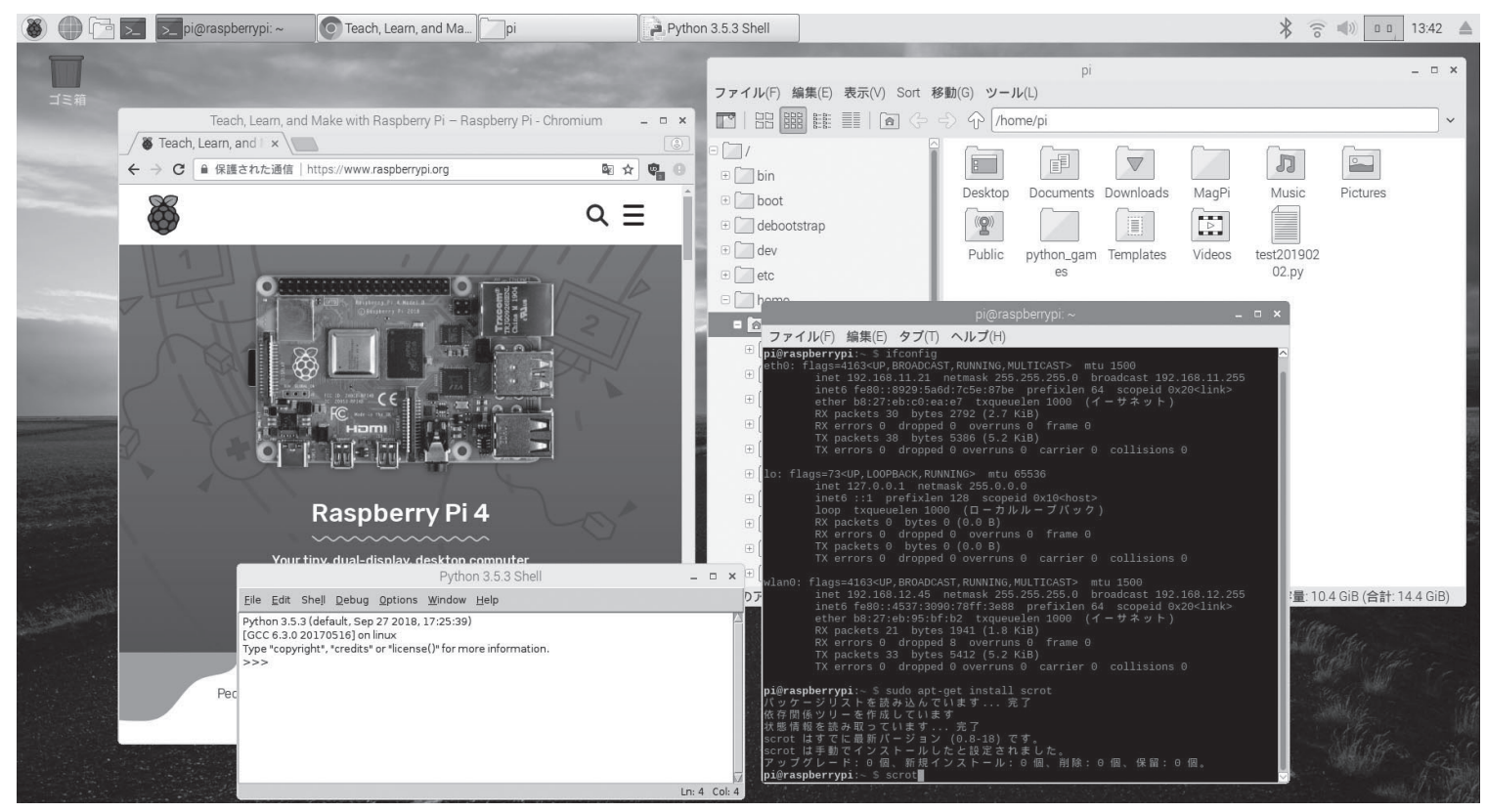

図 4 Raspberry 用 OS である Raspbian の画面

VNC Viewer というソフトウェアがある.このソフトウェア をパソコン側で起動して Raspberry Pi の IP アドレスを指定 すると, Raspberry Pi の画面がそのままパソコン画面内のウ インドウに表示される.

パソコン側で Raspberry Pi のプログラムを開発するため には, NetBeans というソフトウェアを用いる方法もある. これをパソコン側で起動してプログラムを作成し，実行フ アイルを Raspberry Pi に転送して実行させることができる.

Raspberry Piを使うためにはUnix / Linux の知識が必要 なため, マイコンの初心者であれば，まずは Arduino を使 つてみるのが良い. ただし, Raspberry Pi の CPUの方がよ り高速で, メモリも大容量である（代表的なモデル 3B+で $1.4 \mathrm{GHz}$ と $1 \mathrm{~GB})$. また, LAN や Bluetooth 無線接続の機 能も最初から内蔵されているので, より高度な利用目的の ためには, Arduinoよりも適している.

\section{3. パソコン・プログラミング}

パソコンで実行できるプログラムを作成するには，テキ スト形式のソースプログラムや画面に表示されるフォーム のデザインを作成した後, これをコンピュータが理解でき る機械語に変換し, 関連するプログラム部品であるライブ ラリを組込んで, 実行形式のファイルを生成する必要があ る.この作業を効率的に支援してくれるのが統合開発環境 (Integrated Development Environment：IDE）と呼ばれるソ フトウェアである.

IDE には多数の種類があるが, 自分の使用したいプロ グラミング言語と対象のパソコン（Windows, Macintosh, Linux）に合わせて選択する。この解説では，広く利用され ている Microsoft 社の Visual Studio を取り上げる（図 5） ${ }^{4)}$.
Visual Studio には無償版と有償版があるが, 個人で使用す るのであれば無償版で問題ない.

Visual Studio で利用可能な言語は Basic, $\mathrm{C} / \mathrm{C}++, \mathrm{C} \#$ が 代表的である. 今回の解説では $\mathrm{C} / \mathrm{C}++$ の改良版である $\mathrm{C} \#$ を使用する、C\#を用いると， $\mathrm{C} / \mathrm{C}++$ に比較してエラーが生 じにくいプログラムを比較的容易に作成できる.

Visual Studio 以外にも多数の IDE が普及していて, 利用 可能なプログラミング言語も多数ある. 最近では, 人工知 能や機械学習の分野で良く用いられる Python も 1 つの選 択肢となる. Raspberry Pi 用のプログラム作成でも Python が取り上げられることが多い. Arduinoとの連携では, Arduino 用の言語の基になった Processing も使われる. いず れの言語にしても，基本的な考え方は共通であるので，初 心者であれば参考書などを見ながら，まずどれかの言語を 一通り習得するのが良い. 1 つの言語を理解できれば, 他の 言語の習得はずっと容易になるはずである.

\section{4. タブレット・プログラミング}

近年普及が目覚ましいスマートフォンやタブレットであ るが, これらでも自作のプログラムを実行させることがで きる. スマートフォンやタブレットはパソコンに比べて持 ち運びが容易なため, 臨床現場での活用などに適している. 大量の文章の入力には向かないが, 簡単なボタン操作で済 むような作業であれば有効に利用できる.

スマートフォンタブレットは, Apple 社の iPhone / iPad 系と Google 社の Android 系に大きく分かれる. 今回の 解説では, 安価な装置が入手可能な Androidを対象とする. Android 用のプログラムを作成するためには, 統合開発環境 である Android Studio を用いる（図6） ${ }^{5)}$. Android Studio 


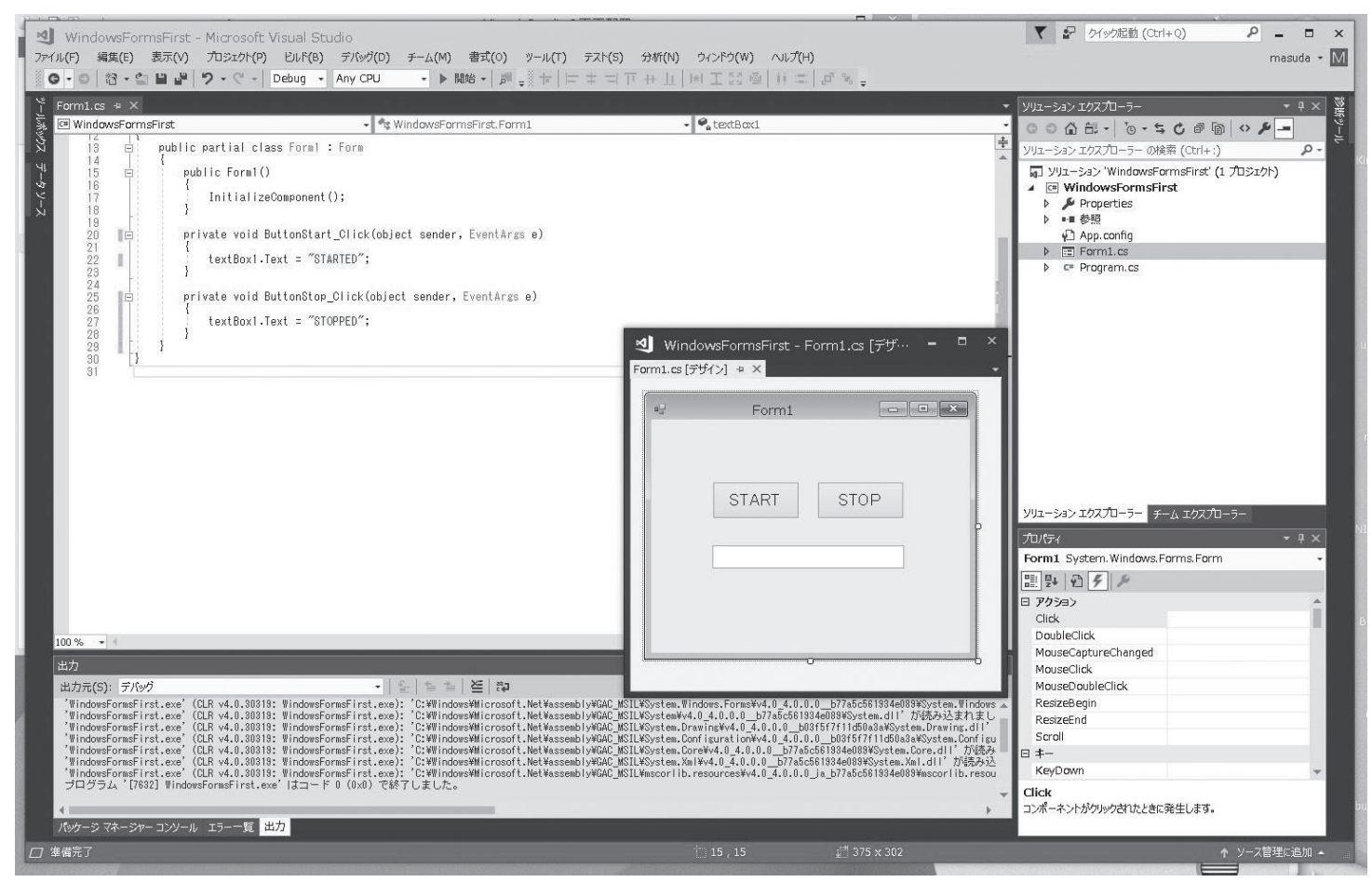

図 5 Visual Studio の画面

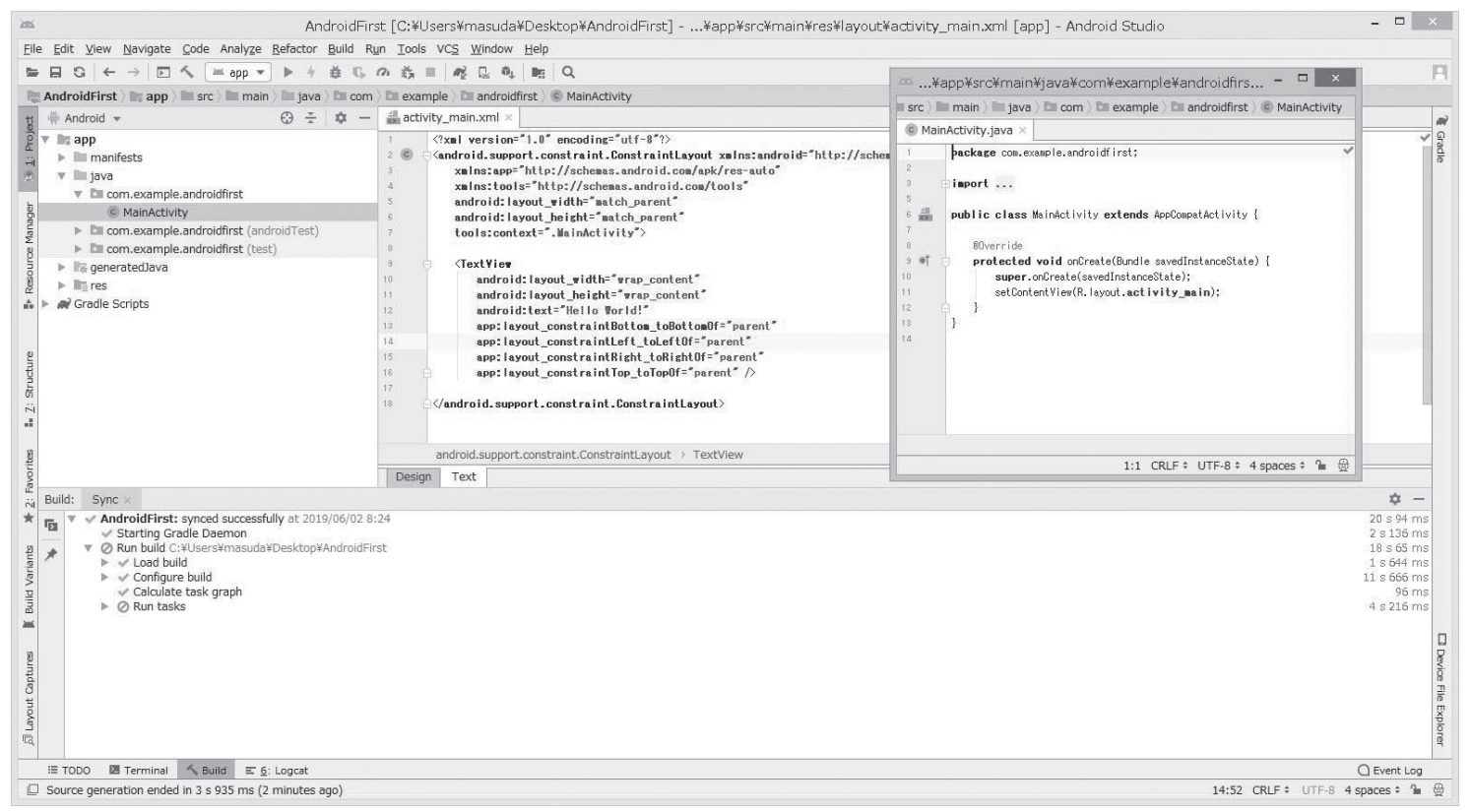

図 6 Android Studio の画面

も無料で利用可能である。このソフトウェアを用いると, 表示画面の設計, プログラムの作成, 作成したプログラム の実行を行うことができる.プログラミング言語はJava が 主流であるが，最近は Java を改良した Kotlin が注目を集め ている ${ }^{6}$. プログラムの実行は，パソコンに接続した実機で も可能であるが, 実機が無くてもパソコン上の仮想端末で も可能である. 従って, 取りあえずタブレットでのプログ ラミングがどのようなものかを試したい場合にはパソコン だけを用意すれば良い。

\section{5. マイコンとの連携}

マイコン, 特に Arduino 単独でできることは限られてい る. マイコンをパソコンあるいはタブレットと連携させる ことにより, マイコンで取り込んだセンサのデータをパソ コンでグラフ化して表示したり, パソコンの指示に従って Arduino に接続した LED を点滅させることができるように なる (図 7).

Arduino との連携ではシリアル通信を使うことができ 


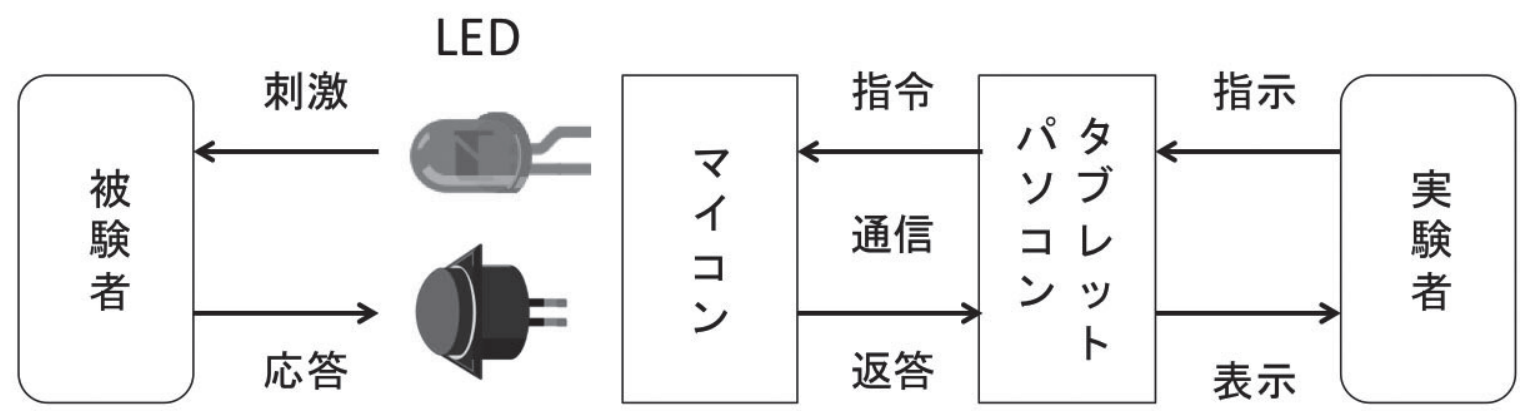

\section{スイッチ}

図 7 Arduino とパソコン /タブレットの連携

る. 有線の場合にはUSB ケーブル経由で, 無線の場合には Bluetooth 経由でパソコンやタブレットと接続できる. パソ コンと接続した場合にはパソコンのシリアルポート（COM ポート）に Arduino が現れる. Arduino が接続された COM ポートの番号をパソコン側で指定し, Arduino とパソコンの 通信速度（baud rate）やビット数などの条件が合うように 設定すると,アルファベットや数字などの文字列を拉互い にやりとりできるようになる.

通信を無線で行いたい場合には, Bluetooth を使うのが 1 つの方法である. Arduino に Bluetooth のモジュールを接続 し,パソコン側には BluetoothのアダプタをUSB 端子に刺す. Bluetooth 経由でもソフトウェア上では COM ポートに接続 されるのでプログラム内で $\mathrm{COM}$ ポートの番号を変更する だけで有線の場合と同様に扱うことができる.

\section{6. まとめ}

次回からの解説で Arduino マイコンの使い方, パソコン でのプログラム作成方法, スマートフォン/タブレットで のプログラム作成方法を取り上げる。 これらを連携させて， LED を点灯させてからスイッチを押すまでの反応時間を計 測し, パソコンやタブレットで受信して表示するという課 題を中心に解説を進める（図 7)。これを応用すれば，スイ ッチが押されてから次に再度押されるまでの時間や，セン サでヒトの動きを検知して動作時間を計測するようなシス テムも容易に作成できるようになる。

紙面の制限から，細かい手順まで触れることはできない が, どのようなハードウェアとソフトウェアを用いれば, どのようなことができるのかは理解して頂けると思う. 個々 の手順は, 書籍やネット上の情報から補うことができるは ずである.

\section{参考文献}

1) 平原真：実践 Arduino!, オーム社, (2018).

2) 牧野浩二: Arduino 電子制御, 東京電機大学出版局, (2015).

3）福田和宏：ラズベリー・パイ超入門, ソーテック社, (2018).

4) 藤本邦昭 : ゼロからはじめる Visual C\#入門, 森北出版, (2018).

5) 齊藤新三:Android アプリ開発の教科書, 翔泳社, (2018).

6) 金田浩明:はじめての Android プログラミング, 第 4 版, SBクリエイティブ, (2019).
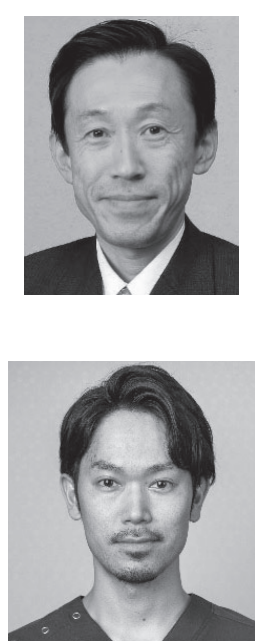

増田正（ますだただし）

1977 年東京大学大学院工学研究科修士 課程修了. 同年通産省製品科学研究所研 究員. 工学博士. 現在, 福島大学特任教授. 主として生体計測, 福祉工学研究開発に 従事.（バイオメカニズム学会正会員）

\section{大路駿介（おおじしゅんすけ）}

2018 年筑波大学大学院人間総合科学研 究科博士前期課程修了. 同年東京医科歯 科大学大学院医歯学総合研究科博士課程 入学. 現在, 東京医科歯科大学医学部附 属病院スポーツ医学診療センターにてス ポーツ傷害・障害のリハビリテーション診療や予防に向け た研究に取り組んでいる.

\section{謝辞}

本連載の原稿に対して有益なご意見を頂きました首都大 学東京, 長谷和徳教授に謝意を表します. 